Research Journal of Applied Sciences 6 (5): 310-319, 2011

ISSN: $1815-932 \mathrm{X}$

(C) Medwell Journals, 2011

\title{
Influence of Solid Loading Concentrations, Inoculums Size and Nitrogen Sources on Ethanol Production from Empty Fruit Bunches (EFB) Hydrolysate in Separate Hydrolysis and Fermentation (SHF)
}

\author{
${ }^{1}$ Mohd Asyraf Kassim, ${ }^{1}$ Nasrin Abu Bakar, ${ }^{1}$ Loh Soh Kheang and ${ }^{2}$ Astimar Aziz \\ ${ }^{1}$ Energy and Environmental Unit, ${ }^{2}$ Agro Product Units, Engineering and Processing Division, \\ Malaysian Palm Oil Board (MPOB), 6 Persiaran Institusi, Bandar Baru Bangi, \\ 43000 Kajang, Selangor, Malaysia
}

\begin{abstract}
Malaysia is one of the largest palm oil producers in the world and the industry has contributed the significant income to the country for many years. With the rapid growth of palm oil production in Malaysia, the amount of biomass residues generated also has shown a corresponding increase. Mass generation of palm biomass particularly Empty Fruit Bunches (EFB) has been identified as one of the main environmental issue generated from palm oil industry. Conversion of EFB into value added products such as bioethanol has been identified as an alternative way to reduce accumulation of EFB in the plantation. In this study, the effects of different EFB concentration, inoculums size and nitrogen sources on bioethanol production using pre-treated EFB were investigated. The pulverized EFB was initially pre-treated with $1 \%(\mathrm{w} / \mathrm{v})$ sodium hydroxide $(\mathrm{NaOH})$ followed by acid hydrolysis using $0.7 \%(\mathrm{v} / \mathrm{v})$ sulfuric acid $\left(\mathrm{H}_{2} \mathrm{SO}_{4}\right)$ and enzymatic saccharification prior to fermentation via Separate Hydrolysis and Fermentation (SHF) mode with Saccharomyces cerevisiae were carried out. The enzymatic hydrolysis process of EFB indicated that the highest glucose concentration was obtained by using $15 \%(\mathrm{w} / \mathrm{v})$ EFB with $26.35 \mathrm{~g} \mathrm{~L}^{-1}$ glucose and $4.6 \mathrm{~g} \mathrm{~L}^{-1}$ xylose, respectively. The fermentation of hydrolysate obtained from saccharified EFB at different solid loading indicated that the highest ethanol production was achieved at $10 \%(\mathrm{w} / \mathrm{v}) \mathrm{EFB}$ with $10.45 \mathrm{~g} \mathrm{~L}^{-1}$ ethanol corresponding to ethanol yield $\left(\mathrm{Y}_{\mathrm{p} / \mathrm{s}}\right)$ of $0.53 \mathrm{~g} \mathrm{~g}^{-1}$ glucose. The most suitable inoculums size for ethanol production from saccharified EFB hydrolysate was $10 \%(\mathrm{v} / \mathrm{v})$ active $S$. cerevisiae and additional of peptone in the EFB hydrolysate was not significantly affected $(\mathrm{p}<0.5)$ the ethanol production. However, additional of peptone in the saccharified EFB hydrolysate was able to reduce period of fermentation from $72-48 \mathrm{~h}$ of incubation.
\end{abstract}

Key words: Empty Fruit Bunches (EFB), enzymatic saccharification, solid loading, inoculums size, nitrogen sources, ethanol

\section{INTRODUCTION}

As the voracious consumption of fossil fuels in anthropogenic enterprise in the last 150 years ultimately exceeded the earth's natural repletion rates, the resultant and alarming shortage of fossil fuels has been of grave concern, worldwide. Consequently, in recent times, the scientific community has increasingly engaged in the development of alternative energy sources where in non-petroleum fuels have emerged as the most promising solution to an imminent fuel crisis.

An increasing demand of non-petroleum fuels prompted extensive research around the globe on cost effective liquid energy such as cellulosic ethanol. Characterized by a higher octane number and flexibility of applications (viz., used in combination with petrol or as net alcohol or carbon in engines), ethanol is now deemed to be the most excellent fuel candidate to replace fossil fuels in the future and has already been introduced on a large scale in Brazil, US and some European countries (Balat and Balat, 2009; Hahn-Hagerdal et al., 2006). Most importantly, ethanol can be sourced from a wide variety of economical raw materials. The greater bulk of cellulosic ethanol is currently being produced from crop residues (sugar cane, corn stover, sweet sorghum baggase, barley straw), hardwood, softwood, starchy materials and even Municipal Solid Waste (MSW) (Kumar et al., 2009; Cardona et al., 2010). Further, the potential for similar production of ethanol lies untapped in the ubiquitous resource called biomass.

Rapid development of palm oil industry in Malaysia has generated an abundance of biomass in the country. In 2009, palm biomass generation in Malaysia totaled 90 millions tons, consisting mainly of Empty Fruit Bunches (EFB), mesocarp fiber, palm kernel cakes, oil palm frond, oil palm trunk and Palm Oil Mill Effluent (POME).

Corresponding Author: Mohd Asyraf Kassim, Energy and Environment Unit, Malaysian Palm Oil Board (MPOB), 6 Persiaran Institusi, Bandar Baru Bangi, 43000 Kajang, Selangor, Malaysia 
Among these, EFB was most abundant with an estimated 6.76 million tons generated from palm oil mills (Choo, 2011). Essentially, EFB is lignocelulosic material that consists of a mixture of carbohydrate polymers, namely: cellulose $(44.2 \%)$, hemicelluloses $(33.5 \%)$ and lignin (20.4\%) (Aziz et al., 2002; Sudiyani et al., 2010). Cellulose is a polymer of the $\alpha$-D-1,4-linked anhydrous glucose unit and hemicellulose is a random, amorphous copolymer comprised of several sugar monomers such as glucose, fructose, xylose and mannose. Consequently, EFB's high cellulose and hemicellulose enable a high potential for conversion into ethanol.

Cellulosic ethanol can be produced in two distinct pathways. Following pretreatment of lignocellulosic material to extract fermentable sugar, cellulosic ethanol may be obtained by fermenting the sugar:

- Via Separate Hydrolysis and Fermentation (SHF)

- Via Simultaneous Saccharification and Fermentation (SSF)

This study employs SHF to achieve its objectives. The economic viability of such ethanol production (from lignocellulosic materials) can be limited by several factors such as the price and performance of enzymes, fermentation efficiency, pretreatment cost and ability to handle high solid concentration of lignocellulosic material (Jorgensen et al., 2007). Typically, ethanol fermentation is carried out under Normal Gravity (NG) conditions with feedstock concentrations of 5-20\% dissolve solids (Nuanpeng et al., 2011). In the regard, ethanol production from very high solid concentrations has been identified as one of the technological maneuvers to increase ethanol productivity and reduce downstream production cost. A higher starting biomass concentration is believed to yield higher product concentration throughout the ethanol production process which in turn, reduces capital and production costs associated with equipment size and energy requirements (Jorgensen, 2009; Um and Hanley, 2008). As explained by Satyanagalakshmi et al. (2011) using high solid concentrations produced low liquid per amount of feedstock which translates to low energy demand and a mass concentrated product stream, the sum of which implies a reduction in ethanol production cost in downstream process. Despite this however, ethanol production at high solid concentration appears to have a negative effect on the fermentation process with respect to the mixture and viscosity of the feedstock during the process (Vaithanomsat et al., 2009). Although, hydrolysis at high solid concentrations produces higher sugar concentrations, it also generates high concentrations of inhibitors that impart increased stress to yeast cells. In addition, high solid concentrations are sluggish and rarely enable the complete fermentation of saccharides (Bafrncova et al., 1999). Fermentation of lignocellulosic ethanol at high solid/feed concentrations can be improved by several means. The first is the addition of nutrients and suitable nitrogen sources such as urea, yeast extract, peptone, ammonium chloride $\left(\mathrm{NH}_{4} \mathrm{Cl}\right)$ and ammonium sulphate $\left(\left(\mathrm{NH}_{4}\right)_{2} \mathrm{SO}_{4}\right)$ which is believed to increase the fermentation rate and ethanol tolerance of yeast (Shafaghat et al., 2010; Yue et al., 2010; Rani et al., 2010). Another factor that influences bioethanol production from biomass feedstock is inoculums size, an increase in which reduces fermentation time/rate and increases ethanol recovery. Based on a study employing molasses, the production of bioethanol increased with increasing inoculums size (Sheela et al., 2008; Mukhtar et al., 2010). Further, studies indicate that ethanol conversion efficiency can be enhanced by optimization of culture condition (Ado et al., 2009). In view of the aforementioned, the purpose of this study resolves to determine:

- Optimal EFB concentration

- Effect of inoculums size and nitrogen source on ethanol productivity and yield by using enzymesaccharified EFB hydrolysate via Separate Hydrolysis and Fermentation (SHF)

\section{MATERIALS AND METHODS}

EFB preparations: EFB was collected from a palm oil mill located in Padang Jawa, Klang. The bunch was dried at $100 \pm 5^{\circ} \mathrm{C}$ and cut into smaller pieces. It was then milled, sieved and separated in fractions using a test sieve shaker. The particle size of EFB used for this study was 91-106 $\mu \mathrm{m}$.

EFB characterization: Dried EFB was initially delignified according to ASTM 1104-56 to produce holocellulose, followed by removal of the hemicellulose fraction using ASTMD1103-60. For holocellulose, approximately $4.0 \mathrm{~g}$ of the ground EFB were mixed with distilled water and treated with $2.0 \mathrm{~mL}$ acetic acid and $5.0 \mathrm{~g}$ sodium chlorite at $70^{\circ} \mathrm{C}$ for $4 \mathrm{~h}$. The mixture was then filtered using filter paper and dried at $103^{\circ} \mathrm{C}$ for $24 \mathrm{~h}$. Determination of holocellulose was carried out using dry weight method. A total of $2.0 \mathrm{~g}$ of dried holocellulose obtained were dissolved in $50 \mathrm{~mL} 17.5 \%(\mathrm{w} / \mathrm{v})$ sodium hydroxide solution and then a total of $70 \mathrm{~mL}$ were added in the mixture in purpose to separate hemicellulose from the holocellulose and leaving $\alpha$-cellulose. The insoluble $\alpha$-cellulose was filtered then, washed with $50 \mathrm{~mL} 8.3 \%(\mathrm{w} / \mathrm{v})$ sodium hydroxide and dried at $103^{\circ} \mathrm{C}$ for $24 \mathrm{~h}$. Determination of $\alpha$-cellulose was carried out using dry weight method. 
Pretreatment of EFB: A total of $5 \mathrm{~g}$ of treated pulverized EFB was initially soaked with $1 \%(\mathrm{w} / \mathrm{v})$ sodium hydroxide $(\mathrm{NaOH})$ at $100^{\circ} \mathrm{C}$ for $2 \mathrm{~h}$. The treated $\mathrm{EFB}$ was then, washed with hot water prior to drying the sample at $103^{\circ} \mathrm{C}$ for $24 \mathrm{~h}$. For the acid hydrolysis process, a total of $5 \mathrm{~g}$ of dried EFB was hydrolysed with $100 \mathrm{~mL} 0.7 \%$ (v/v) $\mathrm{H}_{2} \mathrm{SO}_{4}$ and autoclaved at $125^{\circ} \mathrm{C}$ for $120 \mathrm{~min}$ (Hirayama HVE-50). The treated $\mathrm{EFB}$ was then washed with hot water prior to drying at $103^{\circ} \mathrm{C}$ for $24 \mathrm{~h}$

Enzymatic saccharification: For enzymatic saccharification EFB from the acid hydrolysis process was soaked in a $100 \mathrm{~mL}$ of acetate buffer solution ( $\mathrm{pH} \mathrm{4.8)}$ and mixed with cellulase ( $70 \mathrm{FPU} \mathrm{mL}^{-1}$ ) (Novozymes) at a temperature of $48^{\circ} \mathrm{C}$ and rate of agitation $150 \mathrm{rpm}$ for $48 \mathrm{~h}$. The EFB hydrolysate obtained was used for fermentation and determination of optimum fermentation process parameters.

Scanning electron microscopy: The microstructure of the EFB was viewed using scanning electron microscopy (Hitachi TM-1000). The EFB samples were collected after alkaline and acid hydrolysis process. The treated samples from each pretreatment were filtered and washed using hot water prior to dried at $103^{\circ} \mathrm{C}$ for $24 \mathrm{~h}$. The dried sample was then subjected for microstructure observation.

Inoculums preparation: Saccharomyces cerevisiae was initially grown on Yeast Peptone Glucose (YPG) and was incubated at a temperature of $35^{\circ} \mathrm{C}$ and a rate of agitation $150 \mathrm{rpm}$ for $18-24 \mathrm{~h}$ (Innova 40). In this study, YPG medium consisted of $\left(\mathrm{g} \mathrm{L}^{-1}\right) 10 \mathrm{~g}$ yeast extract, $20 \mathrm{~g}$ peptone and $20 \mathrm{~g}$ glucose. After the incubation period, the cells were then, harvested by centrifugation at $3000 \mathrm{rpm}$ at $4^{\circ} \mathrm{C}$ for $15 \mathrm{~min}$ (Hettich, Universal $32 \mathrm{R}$ ). The pellet was then rinsed twice with sterilized saline solution before being re-suspended in sterilized saline solution to yield an Optical Density (OD) of 1.0 at $600 \mathrm{~nm}$ (Hirayama Model U-200). The standardized S. cerevisiae was used for subsequent study.

Fermentation parameter for ethanol production: Ethanol production from EFB was carried out using hydrolysate obtained from enzymatic hydrolysis process by Separate Hydrolysis and Fermentation (SHF) route. Fermentation of EFB hydrolysate from the pretreatment process was carried out by using $S$. cerevisea ATCC 24860 . A total of $150 \mathrm{~mL}$ of EFB hydrolysate from enzymatic saccharification was prepared in a $250 \mathrm{~mL}$ conical flask. Initially, a total of $10 \%(\mathrm{v} / \mathrm{v})$ of standardized active $S$. cerevisiae was added to the hydrolysate and was incubated at $\mathrm{pH} 4$, temperature at $30^{\circ} \mathrm{C}$ and rate an agitation rate of $100 \mathrm{rpm}$. To determine the effect of solid loading, inoculums size and nitrogen sources on ethanol production, three series of experiments were carried out. For each series of experiments, EFB hydrolysate was harvested every 12-24 h interval. The harvested samples were filtered using a $0.45 \mu \mathrm{m}$ membrane filter and then the filtered samples were put in $2.5 \mathrm{~mL}$ vials prior to being analyzed.

Effect of initial solid loading: The first series of experiments was to determine the effect of initial solid loading on ethanol production. The ranges of solid loading concentration used were between 2.5-30\% (w/v) of dried EFB. Initially, the EFB was pretreated via alkaline, mild acid hydrolysis and followed by enzymatic saccharification. The fermentable sugar obtained from each concentration was harvested at the end of the enzymatic saccharification process and was analyzed. The enzymatically saccharified EFB was subsequently subjected for effect of solid loading on ethanol production. The samples were incubated at $\mathrm{pH} 4,30^{\circ} \mathrm{C}$ with an agitation rate of $100 \mathrm{rpm}$ for $72 \mathrm{~h}$ of incubation.

Effect of inoculums size: A second series of experiments was to determine the effect of inoculums sizes on ethanol production. Four different inoculums size i.e., 5, 10, 15 and $20 \%(\mathrm{v} / \mathrm{v})$ of standardized S. cerevisiae were used in this study and the EFB hydrolysate was incubated at the optimum solid loading obtained at $\mathrm{pH} 4,30^{\circ} \mathrm{C}$ with an agitation rate of $100 \mathrm{rpm}$ for $72 \mathrm{~h}$ of incubation.

Effect of nitrogen sources: The third series of experiments was to determine the effect of nitrogen sources on ethanol production. Four different nitrogen sources i.e, yeast extract, peptone, urea and ammonium chloride $\left(\mathrm{NH}_{4} \mathrm{Cl}\right)$ were used in this study. The enzymatically saccharified EFB hydrolysate was incubated at optimum solid loading and inoculums size obtained from previous testes at $\mathrm{pH} 4$, $30^{\circ} \mathrm{C}$ with an agitation rate of $100 \mathrm{rpm}$ for $72 \mathrm{~h}$ of incubation.

Products analysis: The fermentable sugar and ethanol concentrations in the EFB hydrolysate were determined using High Performance Liquid Chromatography (HPLC) (Waters 2707), Sugar Pack TM1 column: $6.5 \times 300 \mathrm{~mm}$, detector temperature: $35^{\circ} \mathrm{C}$, column temperature: $75^{\circ} \mathrm{C}$, flow rate: $0.5 \mathrm{~mL} \mathrm{~min} \mathrm{~m}^{-1}$ and injector volume of $1 \mu \mathrm{L}$. The ethanol yield (Yp/s) was calculated as the actual ethanol produced and expressed as g ethanol per g total of sugar utilized and the ethanol fermentation efficiency (\%) was calculated based on the ratio of ethanol yield obtained against theoretical maximum ethanol yield. All the kinetics on ethanol fermentation was calculated based on the following Eq. 1-4: 


$$
\begin{gathered}
\text { Fermentation efficiency }(\%)=\left[\frac{\text { Ethanol, } \mathrm{g} \mathrm{L}^{-1}}{\text { Glucose, } \mathrm{g} \mathrm{L}^{-1} \times 0.51}\right] \times 100 \\
\text { Ethanol yield }\left(\mathrm{Y}_{\mathrm{p} / \mathrm{s}}\right)=\left[\frac{\text { Ethanol, } \mathrm{g} \mathrm{L}^{-1}}{\text { Glucose, } \mathrm{g} \mathrm{L}^{-1}}\right] \\
\text { Substrate consumption rate }=\frac{\Delta \mathrm{s}}{\Delta \mathrm{t}} \\
\text { Product formation rate }=\frac{\Delta \mathrm{p}}{\Delta \mathrm{t}}
\end{gathered}
$$

Where:

$\mathrm{S}=$ The initial substrate $\left(\mathrm{g} \mathrm{L}^{-1}\right)$

$\mathrm{P}=$ The actual ethanol produced $\left(\mathrm{g} \mathrm{L}^{-1}\right)$

$\mathrm{t}=$ The time at the optimum ethanol produced $(\mathrm{h})$

Statistical analysis: All the samples were prepared in triplicate. A t-test was carried out to determine the significant differences between the control and the experimental parameters. The statistical analysis was performed using Minitab 14.3 software.
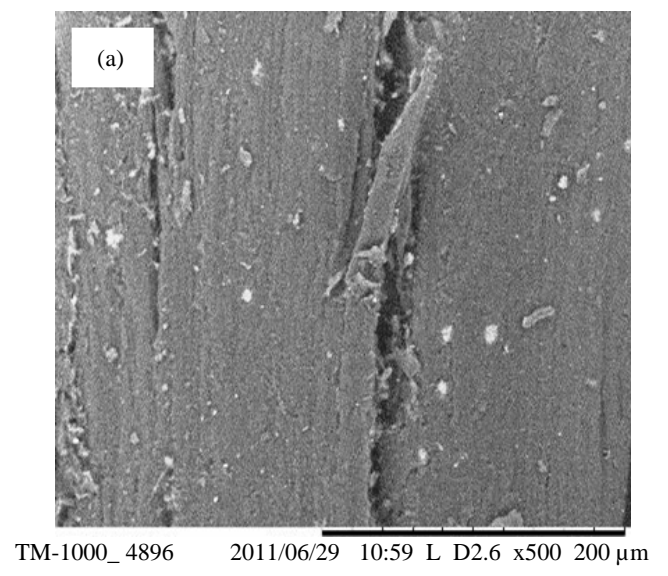

\section{RESULTS}

Table 1 shows the chemical composition of EFB. The major component fraction of EFB is holocellulose $(83.27 \pm 6.11 \%)$, followed by cellulose $(54.17 \pm 6.55 \%)$, hemicellulose (29.10 $44.49 \%)$, lignin(15.13 $\pm 6.10 \%)$ and ash $(2.86 \pm 1.20 \%)$. The significant amount of cellulose in EFB indicates its high potential for use as a fermentation feedstock for ethanol production.

Pretreatment of EFB: Figure 1 shows the SEM image of the microstructure of EFB. The result showed that surface of control EFB was quite smooth with a slight evidence of fissure or pores (Fig. 1a). However, there are pinholes and equatorial grooves were observed in the surface of EFB after treated with $\mathrm{NaOH}$ (Fig. 1b). At the end of acid

Table 1: Chemical composition of Empty Fruit Bunches (EFB)

\begin{tabular}{lc}
\hline Chemical compound & EFB (\%) \\
\hline Lignin & $15.13 \pm 6.10$ \\
Holocellulose & $83.27 \pm 6.11$ \\
$\alpha$-cellulose & $54.17 \pm 6.55$ \\
Hemicellulose & $29.10 \pm 4.49$ \\
Ash & $2.86 \pm 1.20$ \\
\hline
\end{tabular}

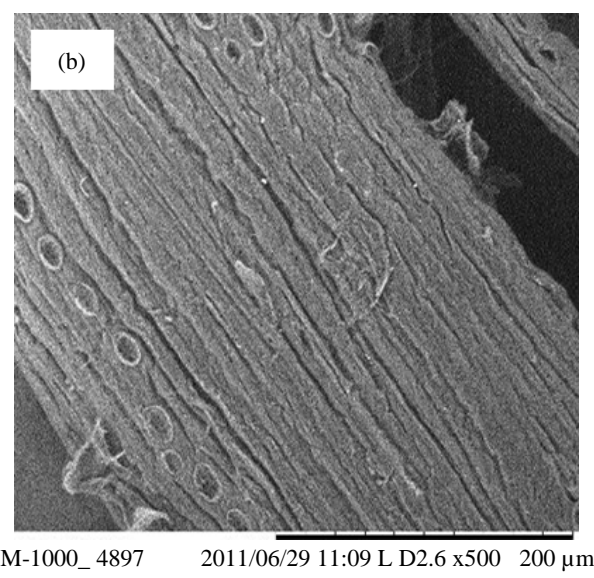

TM-1000_4897 2011/06/29 11:09 L D2.6 x500 200 $\mu \mathrm{m}$

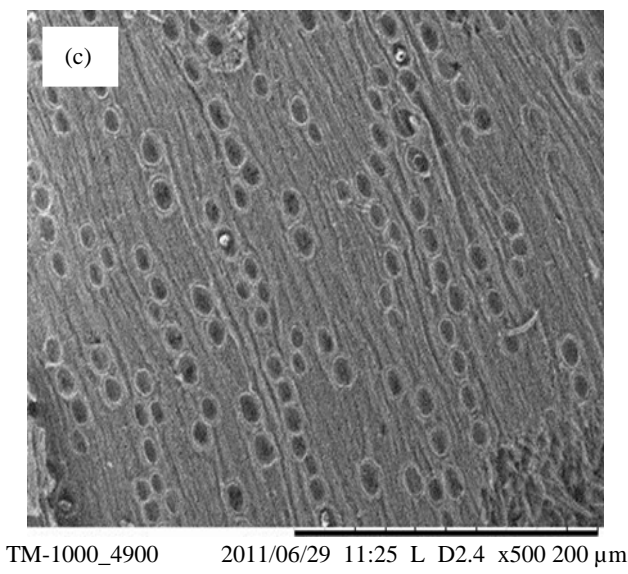

Fig. 1: SEM image at 500x for (a) EFB control (b) alkaline treated EFB (c) acid hydrolysed EFB 


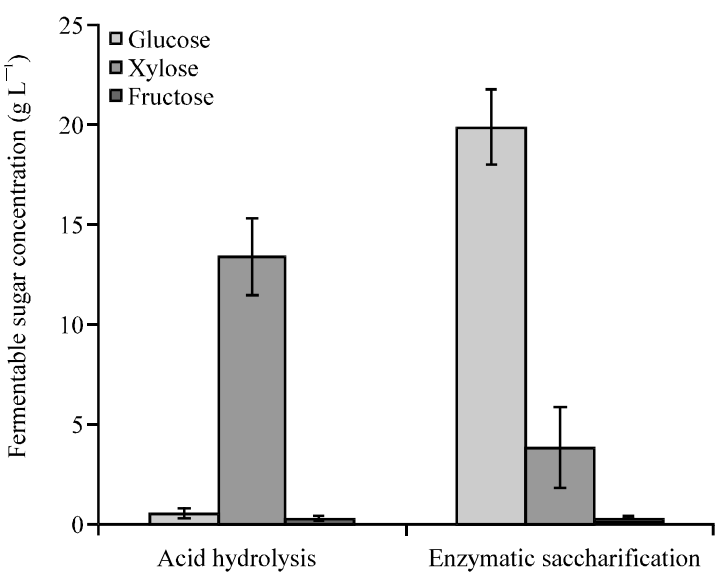

Fig. 2: Fermentable sugar concentration obtained from acid hydrolysis and enzymatic sacchrification treatment

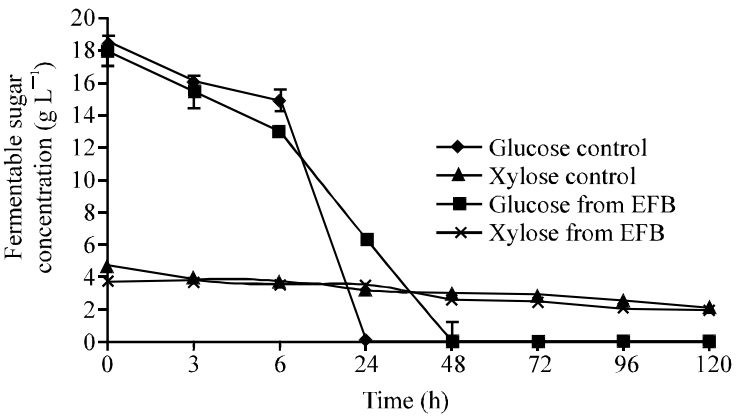

Fig. 3: Fermentable sugar consumption profile from ESE hydrolysate incubated at $\mathrm{pH} 4$, temperature $30^{\circ} \mathrm{C}$ and rate of agitation $100 \mathrm{rpm}$ for $120 \mathrm{~h}$

hydrolysis treatment, it was found that the pinholes and equatorial grooves were become obvious (Fig. 1c). Figure 2 shows fermentable sugar concentrations obtained from EFB pre-treated with acid hydrolysis and enzymatic saccharification. In the pretreatment of EFB to extract fermentable sugars, acid hydrolysis yielded a high concentration of xylose $\left(13.38 \pm 1.89 \mathrm{~g} \mathrm{~L}^{-1}\right)$ and only a small amount of glucose $\left(0.54 \pm 0.23 \mathrm{~g} \mathrm{~L}^{-1}\right)$. In contrast, enzymatic saccharification yielded glucose $\left(19.89 \pm 3.86 \mathrm{~g} \mathrm{~L}^{-1}\right)$ as the dominant fraction, followed by xylose $\left(3.85 \pm 2.02 \mathrm{~g} \mathrm{~L}^{-1}\right)$.

Fermentation of EFB hydrolysate by $S$. cerevisiae: Figure 3 and 4 show the fermentation of Enzymatic Saccharified EFB (ESE) hydrolysate and control, respectively at $30^{\circ} \mathrm{C}$ and an agitation rate of $100 \mathrm{rpm}$ for $120 \mathrm{~h}$. The results reveal that all glucose in the control and the ESE hydrolysate were completely consumed within 24 and $48 \mathrm{~h}$ of incubation, respectively. Thus, glucose was the preferred substrate in both samples and it was consumed before xylose fermentation started.

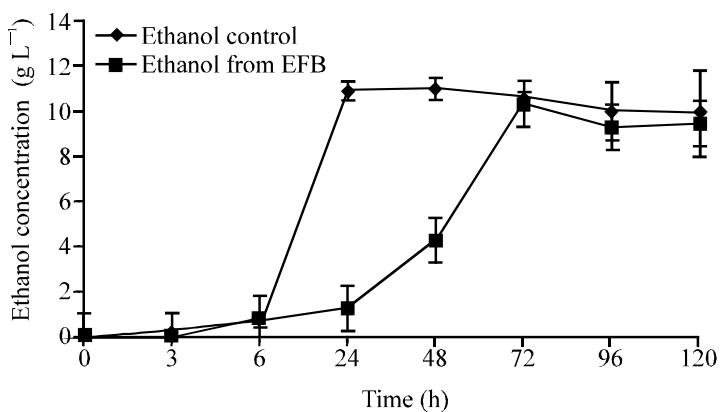

Fig. 4: Bioethanol production from ESE hydrolysate incubated at $\mathrm{pH} 4$, temperature $30^{\circ} \mathrm{C}$ and rate of agitation $100 \mathrm{rpm}$ for $120 \mathrm{~h}$

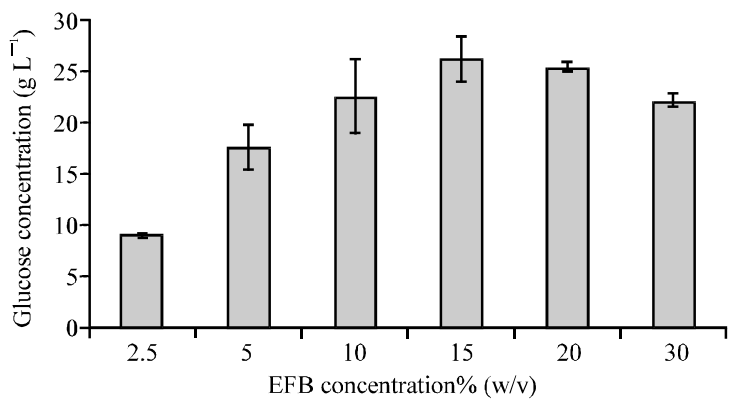

Fig. 5: Fermentable sugar obtained from different EFB concentrations at $48 \mathrm{~h}$ treatment

Corresponding ethanol concentration in the control sample was significantly increased after $6 \mathrm{~h}$ and reached its maximum value $\left(10.92 \mathrm{~g} \mathrm{~L}^{-1}\right)$ at $24 \mathrm{~h}$ which represents the corresponding ethanol yield of $0.59 \mathrm{~g} \mathrm{~g}^{-1}$ glucose consumed. Overall, ethanol production from ESE hydrolysate was found to be slow with a value $\left(10.13 \mathrm{~g} \mathrm{~L}^{-1}\right.$ ) that peaked at $72 \mathrm{~h}$ (corresponding to $0.51 \mathrm{~g} \mathrm{~g}^{-1}$ glucose consumed) and then remained constant thereafter until the end of the process.

Effect of solid loading on bioethanol production: Figure 5 shows fermentable sugar concentrations obtained from different initial EFB concentrations. Production of fermentable sugar initially increased with increments in EFB concentration with 19.76 and $22.44 \mathrm{~g} \mathrm{~L}^{-1}$ of glucose produced from 5 and $10 \%(\mathrm{w} / \mathrm{v})$ of $\mathrm{EFB}$, respectively. The highest sugar concentration $\left(26.35 \mathrm{~g} \mathrm{~L}^{-1}\right)$ was obtained at $15 \%(\mathrm{w} / \mathrm{v}) \mathrm{EFB}$, after which sugar concentrations decreased with increasing of $\mathrm{EFB}$ concentration, yielding 25.31 and $22.03 \mathrm{~g} \mathrm{~L}^{-1}$ of glucose at 20 and $30 \%(\mathrm{w} / \mathrm{v}) \mathrm{EFB}$, respectively. The lowest glucose production $\left(8.92 \mathrm{~g} \mathrm{~L}^{-1}\right)$ was observed at $2.5 \%(\mathrm{w} / \mathrm{v}) \mathrm{EFB}$.

Each of these ESE hydrolysate obtained from each EFB concentration was then fermented by $S$. cerevisiae to evaluate the variation of ethanol production with different initial feedstock concentrations. Figure 6 and 7 show the 


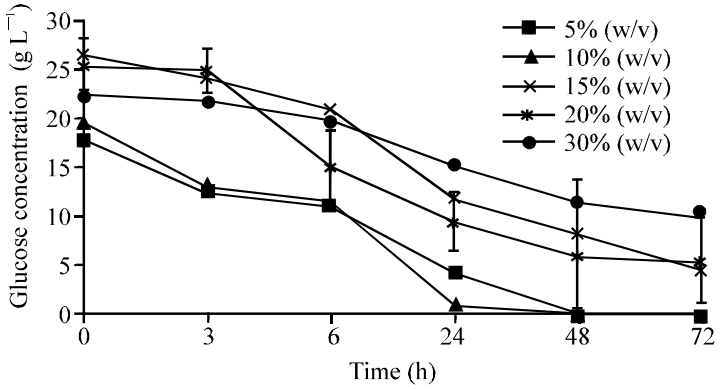

Fig. 6: Glucose consumption by $S$. cerevisiae from different concentration of EFB incubated at an initial $\mathrm{pH}$ of $4,30^{\circ} \mathrm{C}$ and agitated at $100 \mathrm{rpm}$

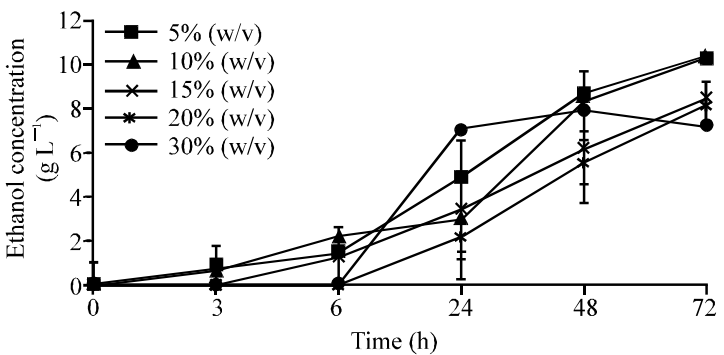

Fig. 7: Ethanol production EFB hydrolysate by $S$. cerevisiae from different concentration of $\mathrm{EFB}$ incubated at an initial $\mathrm{pH}$ of $4,30^{\circ} \mathrm{C}$ and agitated at $100 \mathrm{rpm}$

Table 2: Effect of different EFB concentration on kinetics of ethanol

\begin{tabular}{lccccc}
\hline $\begin{array}{l}\text { Solid } \\
\text { loading } \\
(\%)\end{array}$ & $\begin{array}{c}\text { Glucose } \\
\text { consumption } \\
\text { rate }\left(\mathrm{g} \mathrm{h}^{-1}\right)\end{array}$ & $\begin{array}{c}\text { Ethanol } \\
\text { formation } \\
\text { rate }\left(\mathrm{g} \mathrm{h}^{-1}\right)\end{array}$ & $\begin{array}{c}\text { Ethanol } \\
\text { concentration } \\
\left(\mathrm{g} \mathrm{L}^{-1}\right)\end{array}$ & $\begin{array}{c}\mathrm{Y}_{\mathrm{p} / \mathrm{s}} \\
\left(\mathrm{g} \mathrm{g}^{-1}\right)\end{array}$ & $\begin{array}{c}\text { Fermentation } \\
\text { efficiency (\%) }\end{array}$ \\
\hline 2.5 & 0.18 & 0.06 & 4.43 & 0.49 & 92.98 \\
5.0 & 0.74 & 0.14 & 10.13 & 0.51 & 99.85 \\
10 & 0.27 & 0.14 & 10.45 & 0.50 & 99.35 \\
15 & 0.36 & 0.12 & 8.34 & 0.34 & 62.65 \\
20 & 0.35 & 0.11 & 8.14 & 0.32 & 63.06 \\
30 & 0.31 & 0.10 & 7.19 & 0.33 & 63.84 \\
\hline
\end{tabular}

glucose consumption and ethanol production profiles for different concentrations of EFB. As shown in Fig. 6, glucose was completely consumed by $S$. cerevisiae only in the 5 and $10 \%(\mathrm{w} / \mathrm{v})$ EFB within 48 and $24 \mathrm{~h}$, respectively. Concurrently as shown in Fig. 7, the highest yield of ethanol occurred after $72 \mathrm{~h}$ of incubation from 5 and $10 \%(\mathrm{w} / \mathrm{v})$ EFB which produced 10.26 and $10.36 \mathrm{~g} \mathrm{~L}^{-1}$ ethanol, respectively. These values correspond to ethanol yields $\left(Y_{\mathrm{p} / \mathrm{s}}\right.$ ) of 0.51 and $0.5 \mathrm{~g} \mathrm{~g}^{-1}$ glucose, respectively (Table 2). Ethanol yields from 15 and $20 \%(\mathrm{w} / \mathrm{v}$ ) EFB were lower at $8.34 \mathrm{~g} \mathrm{~L}^{-1}\left(0.34 \mathrm{gg}^{-1}\right.$ glucose $)$ and $8.14 \mathrm{~g} \mathrm{~L}^{-1}$ $\left(0.3 \mathrm{~g} \mathrm{~g}^{-1}\right.$ glucose $)$, respectively.

Effect of inoculums size on bioethanol production: Figure 8 and 9 show glucose consumption and ethanol production profile for different initial inoculums sizes of standardized $S$. cerevisiae. Both glucose consumption

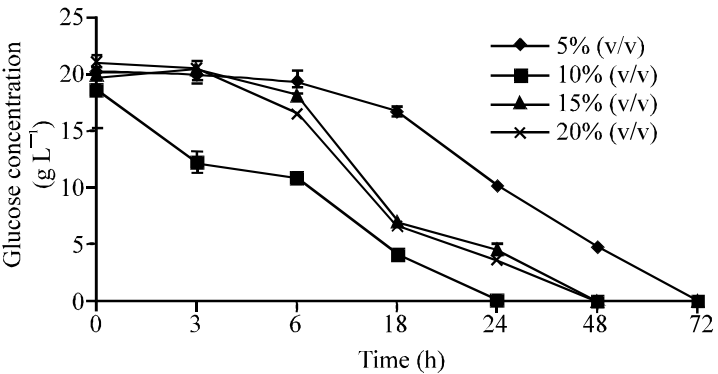

Fig. 8: Glucose consumption by different concentrations of standardized $S$. cerevisiae incubated at an initial $\mathrm{pH}$ of $4,30^{\circ} \mathrm{C}$ and agitated at $100 \mathrm{rpm}$

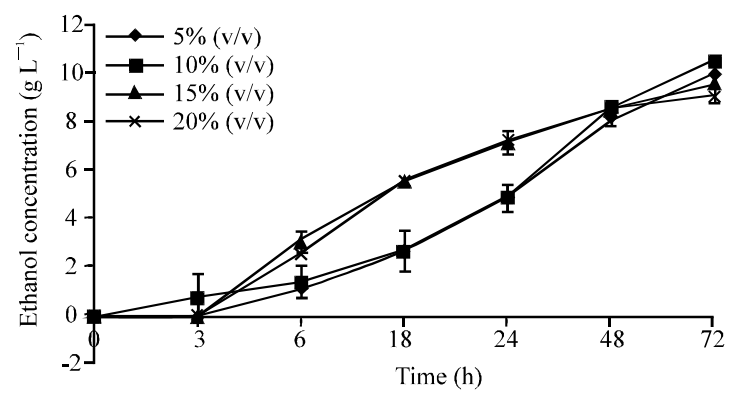

Fig. 9: Ethanol production from EFB hydrolysate by different concentrations of standardized $S$. cerevisiae incubated at an initial $\mathrm{pH}$ of $4,30^{\circ} \mathrm{C}$ and agitated at $100 \mathrm{rpm}$

Table 3: Effect of standardized $S$ cerevisiae concentration on ethanol production

\begin{tabular}{lccccc}
\hline $\begin{array}{l}\text { Inoculum } \\
\text { sizes } \\
(\%)\end{array}$ & $\begin{array}{c}\text { Glucose } \\
\text { consumption } \\
\text { rate }\left(\mathrm{g} \mathrm{h}^{-1}\right)\end{array}$ & $\begin{array}{c}\text { Ethanol } \\
\text { formation } \\
\text { rate }\left(\mathrm{g} \mathrm{h}^{-1}\right)\end{array}$ & $\begin{array}{c}\text { Ethanol } \\
\text { concentration } \\
\left(\mathrm{g} \mathrm{L}^{-1}\right)\end{array}$ & $\begin{array}{c}\mathrm{Y}_{\mathrm{pls}} \\
\left(\mathrm{g} \mathrm{g}^{-1}\right)\end{array}$ & $\begin{array}{l}\text { Fermentation } \\
\text { efficiency (\%) }\end{array}$ \\
\hline 5 & 0.52 & 0.14 & 9.95 & 0.39 & 96.10 \\
10 & 0.77 & 0.14 & 10.45 & 0.50 & 99.35 \\
15 & 0.52 & 0.13 & 9.57 & 0.39 & 94.48 \\
20 & 0.51 & 0.13 & 9.08 & 0.38 & 11.72 \\
\hline
\end{tabular}

and ethanol production rates were directly proportional to increasing inoculums sizes of up to $10 \%(\mathrm{v} / \mathrm{v})$ and thereafter, inversely proportional to inoculums sizes greater than that (Fig. 9). The highest ethanol concentration of $10.45 \mathrm{~g} \mathrm{~L}^{-1}\left(0.5 \mathrm{~g} \mathrm{~g}^{-1}\right.$ glucose $)$ was obtained from inoculation with $10 \%(\mathrm{v} / \mathrm{v}) \mathrm{S}$. cerevisiae and thereafter, declining ethanol concentrations of $9.57 \mathrm{~g} \mathrm{~L}^{-1}\left(0.39 \mathrm{~g} \mathrm{~g}^{-1}\right.$ glucose $)$ and $9.03 \mathrm{~g} \mathrm{~L}^{-1}\left(0.38 \mathrm{~g} \mathrm{~g}^{-1}\right.$ glucose) were produced by 15 and $20 \%(\mathrm{v} / \mathrm{v})$ inoculations, respectively (Table 3 ).

As shown in Fig. 8, the findings also testify to a positive influence of inoculums size in enhancing glucose consumption rate in the EFB hydrolysate. The highest sugar consumption rate was obtained from inoculations with $10 \%(\mathrm{v} / \mathrm{v}) \mathrm{S}$. cerevisiae after only $3 \mathrm{~h}$ and complete consumption occurred within $24 \mathrm{~h}$ of incubation. Inoculations of $15 \%$ and $20 \%(\mathrm{v} / \mathrm{v})$ showed similar trends 


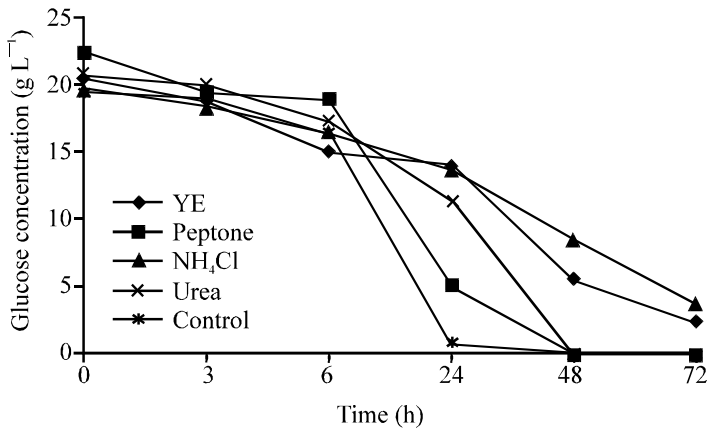

Fig. 10: Glucose consumption by $S$. cerevisiae at different nitrogen sources incubated at an initial $\mathrm{pH}$ of $4,30^{\circ} \mathrm{C}$ and agitated at $100 \mathrm{rpm}$

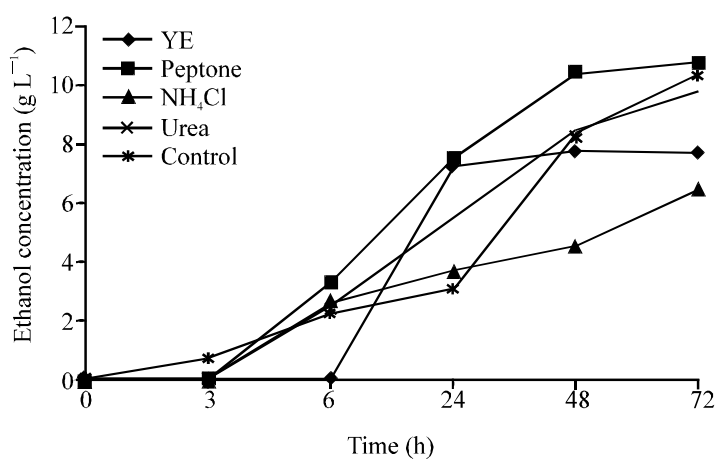

Fig. 11: Ethanol production from EFB hydrolysate by $S$. cerevisiae at different nitrogen sources incubated at an initial $\mathrm{pH}$ of $4,30^{\circ} \mathrm{C}$ and agitated at $100 \mathrm{rpm}$

Table 4: Effect of nitrogen sources on ethanol production

\begin{tabular}{lccccc}
\hline $\begin{array}{l}\text { Nitrogen } \\
\text { sources }\end{array}$ & $\begin{array}{c}\text { consumpe } \\
\text { rate }\left(\mathrm{g} \mathrm{h}^{-1}\right)\end{array}$ & $\begin{array}{c}\text { Ethanol } \\
\text { formation } \\
\text { rate }\left(\mathrm{g} \mathrm{h}^{-1}\right)\end{array}$ & $\begin{array}{c}\text { Ethanol } \\
\text { concentration } \\
\left(\mathrm{g} \mathrm{L}^{-1}\right)\end{array}$ & $\begin{array}{c}\mathrm{Y}_{\mathrm{p} / s} \\
\left(\mathrm{~g} \mathrm{~g}^{-1}\right)\end{array}$ & $\begin{array}{c}\text { Fermentation } \\
\text { efficiency (\%) }\end{array}$ \\
\hline Control & 0.23 & 0.14 & 10.45 & 0.50 & 99.35 \\
YE & 0.42 & 0.11 & 7.70 & 0.38 & 74.37 \\
Peptone & 0.46 & 0.15 & 10.76 & 0.53 & 94.61 \\
Urea & 0.17 & 0.10 & 9.81 & 0.47 & 93.45 \\
$\mathrm{NH}_{4} \mathrm{Cl}$ & 0.17 & 0.09 & 6.45 & 0.33 & 64.16 \\
\hline
\end{tabular}

with complete glucose consumption occurring at $48 \mathrm{~h}$ of incubation. However, an inoculums size of $5 \%(\mathrm{v} / \mathrm{v}) S$. cerevisiae showed the lowest glucose consumption rate, at about $0.52 \mathrm{~g} \mathrm{~h}^{-1}$, requiring $>72 \mathrm{~h}$ of incubation to be completely consumed (Fig. 8).

Effect of nitrogen sources on bioethanol production: Experimentation with various nitrogen additives to the ESE hydrolysate and unsupplemented control revealed that peptone was the best choice of a nitrogen source that positively affects the fermentation process (Fig. 10 and 11). Peptone facilitated a heightened ethanol concentration of $10.76 \mathrm{~g} \mathrm{~L}^{-1}$ (viz., an ethanol yield of $0.53 \mathrm{~g} \mathrm{~g}^{-1}$ glucose consumed) (Table 4). Interestingly however, the ethanol yield $\left(\mathrm{Y}_{\mathrm{p} / \mathrm{s}}\right)$, for peptone-added ESE hydrolysate was not significantly different from that for unsupplemented ESE although, the former demonstrated a shorter fermentation period than the latter. Figure 11 shows how peptone addition reduced the optimum fermentation period from $72-48 \mathrm{~h}$. Also the results show that the addition of yeast extract and $\mathrm{NH}_{4} \mathrm{Cl}$ to the ESE hydrolysate produced lower ethanol concentrations of $7.7 \mathrm{~g} \mathrm{~L}^{-1}\left(0.38 \mathrm{~g} \mathrm{~g}^{-1}\right.$ glucose consumed) and $6.45 \mathrm{~g} \mathrm{~L}^{-1}$ (0.33 $\mathrm{g} \mathrm{g}^{-1}$ glucose consumed) respectively than that produced from the unsupplemented control (Table 4). Conclusively, $\mathrm{NH}_{4} \mathrm{Cl}$ and yeast are not suitable as an additive for bioethanol production from ESE hydrolysate.

\section{DISCUSSION}

Due to the inevitable depletion of fossil fuel coupled with environmental problems, ethanol production from lignocellulosic materials has been gaining great attention as an alternative fuel. Ethanol production from lignocellulosic biomass can be carried out using series of process i.e., pretreatment using alkaline or acid hydrolysis, enzymatic saccharification and fermentation (Demirbas, 2005). In this present study, pretreatment of EFB using combination of alkaline and mild acid hydrolysis showed a promising approach to extract fermentable sugar from EFB. Based on the Fig. 1, combination of alkaline and mild acid hydrolysis is able to enhance the EFB's structure and made it accessible to the attack during acid hydrolysis and improves enzymatic saccharification. According to Sun and Cheng (2002), pretreatment of lignocelluloses material using alkaline treatment will increase internal surface area and porosity, decrease the degree of polymerization and crystallinity, separate structural linkages between lignin and carbohydrates and disrupt the lignin structure. As can be shown in the Fig. 2, results show that the major sugar obtained from the acid hydrolysis was xylose. Generally, the proton in the mixture could catalyze and scissor the $\beta-1,4$, linkage of glucose and xylose monomer, acetyl group and other products into cellulose and hemicellulose in the biomass (Najafpour et al., 2007; Taherzadeh and Karimi, 2007). The present study also shows that glucose is the major fermentable sugar obtained from enzymatic hydrolysis (Fig. 2). This may be due to the high presence of cellulose in the pretreated EFB. High glucose concentration extracted from EFB may be due to the fact that cellulose contained in the EFB is degraded by cellulases into reducing sugars mainly glucose during the enzymatic saccharification (Lynd et al., 2002). Moreover, most of the hemicelluloses and xylose have been washed out during sample preparation process. Based on the data 
obtained, high concentration fermentable sugar extracted from EFB shows it potential to become as feedstock for ethanol production. Thus, in order to produce ethanol from EFB, the fermentation of enzymatically saccharified EFB hydrolysate was fermented using S. cerevisea.

The economic feasibility of bioethanol production from fermentation of lignocellulosic materials relies heavily on optimal initial solid loading. Such high loadings translate to high substrate concentrations (viz., high sugar content) which is required to obtain high ethanol yields (Zhang and Heng, 2010). Congruently, this study showed that the production of fermentable sugar increased with increments in concentration of EFB although, concentrations $>20 \%(\mathrm{w} / \mathrm{v})$ EFB demonstrated just the opposite effect on the amount of fermentable sugar extracted. This result is in agreement with the study of Lu et al. (2008) who reported similarly reduced final sugar concentrations when using high substrate concentrations in enzymatic hydrolysis.

The lower sugar content obtained at high solid loading is likely due to the high viscosity that results in insufficient dispersion of substrate and less efficient enzyme activity in the vessel ( $\mathrm{Lu}$ et al., 2008). Poor enzyme distribution has the effect of localized hydrolysis product build-up in the vessel (Roche et al., 2009). Hydrolysis at high solid concentration brings about low enzyme reaction rates which impede the liquefaction of cellulose material (Um and Hanley, 2008). The research of Kristensen et al. (2009) on the effect of solid loading on hydrolysis conversion of filter paper, revealed that any increase of solid loading above $20 \%(\mathrm{w} / \mathrm{v})$ resulted in low cellulose absorption and consequently, low sugar concentration and conversion rate. Further, high substrate concentrations yielded low sugar concentrations due to product-inhibitory action by glucose and cellubiose that is generated during the enzamytic saccharification process (Hodge et al., 2008).

Next, in the fermentation of the extracted sugar, this study's finding indicates that the fermentation of high concentrations of EFB-hydrolysate produced low ethanol concentrations. The data obtained is in agreement with that the study of Zhang and Feng (2010) who reported that ethanol fermentation at high substrate concentrations produce lower ethanol productivity. Manikandan et al. (2008) in their study of the effect of banana peel concentrations on ethanol production, explained that low ethanol productivity may be probably due to the presence of inhibitors such as furfural and Hydroxymethylfurfural (HMF) in the banana hydrolysate which is produced during the pretreatment process and which is toxic to microorganisms thereby imparting a negative effect on the fermentation process (Klinke et al., 2004; Stenberg et al.,
1999). Such a negative effect of inhibitors on ethanol production was clearly observed by Lu et al. (2008) when high solid loading was used in the fermentation process.

Suitable inoculums size is important to achieve better fermentation rate and ethanol production although, excessive inoculums in the medium compromises ethanol production and recovery (Jones et al., 2007). This makes optimal inoculums size a critical determinant of efficient ethanol production from EFB. Correspondingly, this study demonstrates that increases in inoculums size increased ethanol concentration and sugar consumption rates (Fig. 8 and 9) although, further increases of inoculums size, above $20 \%(\mathrm{v} / \mathrm{v})$ of $S$. cerevisea, resulted in lower ethanol production and glucose consumption rate. A similar observation has been reported by Sheela et al. (2008) in a study on ethanol production from molasses by $S$. cerevisiae, wherein ethanol production increased with increasing inoculums size, up to a point and then declined with increasing inoculums size, thereafter. In this context, $\mathrm{Vu}$ and Kim (2009) suggested that a lower initial cell number would result in lower ethanol production and require a longer period to complete the fermentation process.

An additional nitrogen source is a necessary facilitation for the growth and multiplication of yeast and it influences the ethanol tolerance of yeast and the ultimate ethanol productivity (Bafrncova et al. 1999). In the study, the addition of various nitrogen sources to the ESE hydrolysate did not have any significant influence on ethanol production with the exception of peptone's reductive effect on fermentation period from $72-48 \mathrm{~h}$. The same trend has been reported by Bafrncova et al. (1999) who demonstrated that an additional nitrogen source was not able to increase ethanol productivity although, it did increase glucose consumption rate up to 3 times that of the control. In further support of the study's findings, $\mathrm{Vu}$ and Kim (2009) demonstrated that the addition of proper nitrogen sources such as urea and yeast extract in the fermentation medium decreased fermentation period from 114-90 $\mathrm{h}$.

Nutrient sources such as Free Amino Nitrogen (FAN) are found to influence yeast viability and fermentation ability thereby increasing productivity and final ethanol yield (Pradeep et al., 2010; O'Connor-Cox et al., 1991). FAN is an excellent source of nitrogen for yeast and increasing FAN content by proteolytic degradation of protein present in substrate brings about an increase in fermentation performance (Jorgensen et al., 2007). The addition of FAN is especially suitable for ethanol fermentation in Very High Gravity media (VHG) where in FAN provides the sufficient lipids, minerals and vitamins to tolerate gravity induced stress on the yeast cells 
(Thomas et al., 1994). In this study, the addition of inorganic nitrogen sources such $\mathrm{NH}_{4} \mathrm{Cl}$ to the ESE hydrolysate resulted in lower ethanol concentrations than that in the unsupplemented control (Fig. 11) which indicates that these nitrogen sources were not suitable for supplementation in bioethanol production. This unsuitability of $\mathrm{NH}_{4} \mathrm{Cl}$ may be explained by the presence of additional nitrate salts in an acidic medium (with $\mathrm{pH}<6$ ), resulting in the formation of nitrous acid in the medium which is toxic to yeast cells and subsequently decreases ethanol production ( $\mathrm{Vu}$ and Kim, 2009; Isono and Hoshino, 2000).

\section{CONCLUSION}

The results of this study establish EFB's substantial potential as an ethanol production feedstock in the future. The ethanol yield of EFB improved with modification of medium composition and inoculums size. The maximum ethanol concentration from Enzymatically Saccharified $\mathrm{EFB}$ (ESE) hydrolysate was between 10.36 and $10.76 \mathrm{~g} \mathrm{~L}^{-1}$, at $100 \mathrm{~g} \mathrm{~L}^{-1}, 10 \%(\mathrm{v} / \mathrm{v})$ standardized $S$. cerevisiae and addition of peptone incubated at a $\mathrm{pH}$ of 4 , at $30^{\circ} \mathrm{C}$ and at an agitation rate of $100 \mathrm{rpm}$. The addition of peptone as a nitrogen source, reduced fermentation period and increased fermentation rate. The scope of future research includes scaled-up experimentation in a larger scale bioreactor (operated in optimum conditions) and an indepth, economic study of ethanol production from EFB.

\section{ACKNOWLEDGEMENTS}

The researchers would like to thank Director-General of Malaysian Palm Oil Board (MPOB) for permission granted to publish this study. Thanks are also due to all staff of Energy and Environment Unit, MPOB for their valuable assistance and technical supports.

\section{REFERENCES}

Ado, S.A., G.B. Olukotun, J.B. Ameh and A. Yabaya, 2009. Bioconversion of cassava starch to ethanol in a simultaneous saccharification and fermentation process by co-culture of Aspergilus niger and Saccharomyces cerevisiae. Sci. World J., 4: 19-22.

Aziz, A.A., K. Das, M. Husin and A. Mukhtar, 2002. Effect of physical and chemical pre-treatment of xylose and glucose production from oil palm press fibre. J. Oil Palm Res., 14: 10-17.

Bafrncova, P., D. Smogrovicova, I. Slavikova, J. Patkova and Z. Domaeny, 1999. Improvement of very high gravity ethanol fermentation by media supplementation using Saccharomyces cerevisiae. Biotechnol. Lett., 21: 337-341.
Balat, M. and H. Balat, 2009. Recent trends in global production and utilization of bio-ethanol fuel. Applied Energ., 86: 2273-2282.

Cardona, C.A., J.A. Quintero and I.C. Paz, 2010. Production of bioethanol from sugarcane bagasse: Status and perspectives. Bioresour. Technol., 101: 4754-4766.

Choo, Y.M., 2011. Overview of the Malaysian oil palm industry 2010. http://econ.mpob.gov.my/economy/ Overview_2010_final.pdf.

Demirbas, A., 2005. Bioethanol from cellulosic materials: A renewable motor fuel from biomass. Energy Sources A Recovery Utilization Environ. Effects, 27: 327-337.

Hahn-Hagerdal, B., M. Galbe, M.F. Gorwa-Grauslund, G. Liden and G. Zacchi, 2006. Bio-ethanol: The fuel of tomorrow from the residues of today. Trends Biotechnol., 24: 549-556.

Hodge, D., K.M. Karim, D.J. Schell and D. McMillan, 2008. Soluble and insoluble solid contribution to high solid enzymatic hydrolysis of lignocellulosic. Bioresour. Technol., 99: 8940-8948.

Isono, Y. and A. Hoshino, 2000. Production of ethanol using granulated yeast cells prepared by a spray dryer. J. Gen. Applied Microbiol., 46: 231-234.

Jones, H.L., A. Margaritis and R.J. Stewart, 2007. The combined effects of oxygen supply strategy, inoculums size and temperature profile on very-highgravity beer fermentation by Saccharomyces cerevisiae. J. Inst. Brew., 113: 168-184.

Jorgensen, H., 2009. Effect of nutrients on fermentation of pretreated wheat straw at very high dry matter content by Saccharomyces cerevisiae. Applied Biochem. Biotechnol., 153: 44-57.

Jorgensen, H., J. Vibe-Pedersen, J. Larsen and C. Felby, 2007. Liquefaction of lignocellulose at high-solids concentrations. Biotechnol. Bioeng., 96: 862-870.

Klinke, H., A. Thomsen and B. Ahring, 2004. Inhibition of ethanol-producing yeast and bacteria by degradation products produced during pre-treatment of biomass. Applied Microbiol. Biotechnol., 66: 10-26.

Kristensen, J.B., C. Felby and H. Jorgensen, 2009. Yielddeterminating factor in high-solids enzymatic hydrolysis of lignocelluloses. Biotechnol. Biofuels, 2: 11-11.

Kumar, P., D.M. Barrett, M.J. Delwiche and P. Stroeve, 2009. Methods for pretreatment of lignocellulosic biomass for efficient hydrolysis and biofuel production. Ind. Eng. Chem. Res., 48: 3713-3729.

Lu, Y., Y. Wang, G. Xu, J. Chu, Y. Zhuang and S. Zhang, 2008. Influence of high solid concentration on enzymatic hydrolysis and fermentation of steamexploded corn stover biomass. Applied Biochem. Bioetchnol., 160: 360-369. 
Lynd, L.R., P.J. Weimer, W.H. van Zyl and I.S. Pretorius, 2002. Microbial cellulose utilization: Fundamentals and biotechnology. Microbiol. Mol. Biol. Rev., 66: 506-577.

Manikandan, K., V. Saravanan and T. Viruthagiri, 2008. Kinetics studies on ethanol production from banana peel waste using mutant strain of Saccharomyces cerevisiae. Indian J. Biotechnol., 7: 83-88.

Mukhtar, K., M. Asgher, S. Afghan, K. Hussain and S. Zia-ul-Hussnain, 2010. Comparative study on two commercial strains of Saccharomyces cerevisiae for optimum ethanol production on industrial scale. J. Biomed. Biotechnol., 2010: 1-5.

Najafpour, G., A. Ideris, S. Salmanpour and M. Norouzi, 2007. Acid hydrolysis of pretreated palm oil lignocellulosic wastes. Int. J. Eng. (Trans. B: Appl.), 20: 147-156.

Nuanpeng, S., L. Laopaiboon, P. Srinophakun, P. Klanrit, P. Jaisil and P. Laopaiboon, 2011. Ethanol production from sweet sorghum juice under very high gravity condition: Batch, repeated-batch and scale up fermentation. Electron. J. Biotechnol., 10.2225/voll 4issue 1-fulltext-2.

O'Connor-Cox, E.S.C., J. Paik and W.M. Ingledew, 1991. Improved ethanol yield through supplementation with excess assimilable nitrogen. J. Ind. Microbiol. Biotechnol., 8: 45-52.

Pradeep, P., G.K. Goud and O.V.S. Reddy, 2010. Optimization of Very High Gravity (VHG) finger milet (ragi) medium for ethanolic fermentation by yeast. Chiang Mai J. Sci., 37: 116-123.

Rani, P., S. Sharma, F.C. Garg, K. Raj and L. Wati, 2010. Ethanol production from potato flour by Saccharomyces cerevisiae. Indian J. Sci. Technol., 3: 733-736.

Roche, C.M., C.J. Dibble and J.J. Stickel, 2009. Laboratoryscale method for enzymatic saccharification of lignocellulosic biomass at high solid loadings. Biotechnol. Biofuels, 2: 28-28.

Satyanagalakshmi, K., R. Sindhu, P. Binod, K.U. Janu, R.K. Sukumaran and A. Pandey, 2011. Bioethanol production from acid pretreated water hyacinth by separate hydrolysis and fermentation. J. Sci. Ind. Res., 70: 156-161.

Shafaghat, H., G.D. Najafpour, P.S. Rezaei and M.S. Sharifzadeh, 2010. Optimal growth of Saccharomyces cerevisiae (PTCC 24860) on pretreated molasses for the ethanol production: The application of the response surface methodology. Chem. Ind. Chem. Eng. Q., 16: 199-206.
Sheela, S.H., M.F. Ahmed and D.J. Gomez, 2008. Fuel ethanol production from molasses by some indigenous yeast isolates. Bangladesh J. Microbiol., 25: 129-133.

Stenberg, K., M. Bollok, K. Reczey, M. Galbe and G. Zacchi, 1999. Effect of substrate and cellulase concentration on simultaneous saccharification and fermentation of steam-pretreated softwood for ethanol production. Biotechnol. Bioeng., 68: 204-210.

Sudiyani, Y., K.C. Sembiring, H. Hendarsyah, N. Ariani and S. Alawiyah, 2010. Alkali pretreatment and enzymatic saccharification of oil palm empty fruit bunch for ethanol production. Menara Perkebunan, 78: 34-38.

Sun, Y. and J. Cheng, 2002. Hydrolysis of lignocellulosic materials for ethanol production: A review. Bioresour. Technol., 83: 1-11.

Taherzadeh, M.J. and K. Karimi, 2007. Acid-based hydrolysis processes for ethanol from lignocellulosic materials: A review. BioResources, 2: 472-499.

Thomas, K.C., A. Dhas, B.G. Rossnagel and W.M. Ingledew, 1994. Production of fuel alcohol from hull-less barley by very high gravity technology. Cereal Chem., 72: 360-364.

Um, B.H. and T.R. Hanley, 2008. High-solid enzymatic hydrolysis and fermentation of solka floc into ethanol. J. Microbiol. Biotechnol., 18: 1257-1265.

Vaithanomsat, P., S. Chuichulcherm and W. Apiwatanapiwat, 2009. Bioethanol production from enzymatically sacharified sunflower stalks using steam explosion as pretreatment. World Acad. Sci. Eng. Technol., 49: 140-143.

$\mathrm{Vu}, \mathrm{V} . \mathrm{H}$. and K. Kim, 2009. Ethanol production from rice winery waste-rice wine cake by simultaneous saccharification and fermentation without cooking. J. Microbiol. Biotechnol., 19: 1161-1168.

Yue, G., J. Yu, X. Zhang and T. Tan, 2010. The influence of nitrogen sources on ethanol production by yeast from concentrated sweet sorghum juice. Biomass Bioenergy (in Press) DOI: 10.1016/j.biombioe. 2010. 08.041 .

Zhang, K. and H. Feng, 2010. Fermentation potential of Zymomonas mobilis and its application in ethanol production from low-cost raw sweet potato. Afr. J. Biotechnol., 9: 6122-6128. 